\title{
An empirical exploration of consumer buying behaviour in the age of luxury branding - With special reference to the Chennai retail market
}

\begin{abstract}
Luxury branding seems to be the emerging trendsetter in the Indian Retail sector. With the growth in India's consumer market primarily driven by a favorable population composition and rising disposable incomes, luxury brands have started getting a foothold in the Indian market. Luxury brand owners see growth opportunities in cities like Bangaluru, Hyderabad, Kolkata and Chennai after serving the most important luxury markets of Delhi and Mumbai. This study focuses on the entry of luxury brands in the Chennai retail space and the strategies that luxury brands are employing to target customers who want to purchase luxury brands because of their brand image, exclusivity and excellent quality. The paper discusses how luxury brands with high quality, uniqueness and social value will appeal to people of different age groups, occupations, income groups and gender. Structural Equation Modelling has been employed to help marketers to understand how consumers perceive luxury brands and what features are considered most important by them. The study also provides insights for further research in the field of consumer behaviour and luxury branding.
\end{abstract}

Nisha U
Index Terms : Consumer behaviour, Cluster wise marketing Luxury branding, Retail sector.

\section{INTRODUCTION}

This India's ascendance as an economic power to reckon with, has forced the world to unravel the mystery called India. An intriguing element of this mystery is India's consumer market; characterized by diverse languages, regions, religions, economic and social status, this market has always been a tricky proposition to understand (Jain, Prerna., 2013). The KS Oils Limited (2014) report stated that as the consumer market has undergone a paradigm shift due to India's rapid economic growth and favourable demographics, it has also become a market impossible to dismiss.

According to a report by the Retailers Association of India (2015), the predominate role played by social media and technology has changed the way Indian consumers shop, regardless of their education, age, income and economic scenario. India being the second-fastest growing economy is believed to be one of the most sought after market for luxury brands. The luxury market in India is gaining increasing visibility with each passing year. (Bothra, Neha., 2013).
Indian consumers have been acquainted with Luxury brands abroad through imports, however now with India being a lucrative option, leading luxury brands have opened stores in the Indian market. India and other emerging markets are prospective markets for the luxury brands. Luxury brands are unique in the sense that it is not the product which is being sold but solely the brand. (Chatterjee, Purvita., 2016).

The distinction between necessity and luxury is based on the availability or exclusivity of resources. While necessities are possessed by virtually everyone, luxuries are available exclusively to only a few people or at least only on rare occasions (Bearden and Etzel, 1982).

Bearden and Etzel (1982) imagined the necessity-luxury dimension as a continuum ranging from absolute necessity to absolute luxury. Accordingly, they developed a six-point Likert scale ranging from 'a necessity for everyone' to 'a luxury for everyone' in order to measure the luxuriousness of a number of product categories.

However, not everything that is neither necessary nor ordinary is a luxury (Berry, 1994). While necessary and ordinary goods are also desirable or required, a study by Kemp (1998) points out an essential difference similar items are more likely to be perceived as a luxury if they produce a positive effect for the recipient than if they relieve a state of discomfort so that luxuries are positive instead of negative reinforcements.

\section{LITERATURE REVIEW}

The literature review has been divided into the following sections,

\section{A. Meaning and context of luxury and luxury brands}

Researchers across all disciplines share a basic understanding of luxury. To begin with, luxury is defined as something that is more than necessary (Bearden and Etzel,1982) . In contrast to necessity, some authors also characterize luxury by non-necessity and superfluity (De Barnier et al, 2006). Appadurai (1986) lists five characteristics of luxury, (1) Restriction to elites by law or price (2) Complexity of acquisition - which may or may not reflect real 'scarcity' (3) 


\section{An empirical exploration of consumer buying behaviour in the age of luxury branding - With special reference to the Chennai retail market}

Semiotic virtuosity (4) Codes for 'appropriate' consumption demanding specialized knowledge (5) High degree of linkage of their consumption to body, person and personality. Such a position assumes human needs, at least primary needs, to be fundamental instincts or reflexes. Berry (1994) characterizes luxury goods as items that rise desire and provide pleasure to its consumers.

Nia and Zaichkowsky (2000) argue that luxury goods enable consumers to satisfy their functional and psychological needs, and that this is what makes the distinction between luxury and non-luxury goods, as non-luxury goods do not fulfil the psychological need because they are not able to provide esteem to its owners.

\section{B. Growth of luxury brands in India and Chennai}

Michael Boroian and Alix de Poix (2009) state that the Indian luxury market is culturally complex and dynamic. Glyn Atwal and Soumya Jain (2012) undertook a luxury journey of India, starting with its history of luxury, understanding consumption patterns and codes of consumption. In their analyses they conclude that Indian consumers have an inclination to towards luxury when it comes to ceremonies and celebrations. They do not think twice to spend on luxury clothing for grand weddings. Sreedevi, K (2013) has investigated the presence of grand stylish shopping malls in the city of Chennai. The author states that to keep up with the trend, new malls in the city are managing to rope in traditional and popular luxury brands into their fold. Shopping malls in the have become a favourite destination for of global luxury brands vying a toehold in the city.

\section{Consumer preferences for brands}

Understanding and adapting to changes in consumer needs is an important aspect for survival in a continuously changing environment. Various demographic, psychological and social variables have an impact on a consumer's purchase behaviour and preferences. In India consumers' shopping behaviour is affected by demographic factors such as age and gender. With women joining the workforce, shopping patterns have changed. Women prefer a wider range of brands so that they can compare different brands before making a choice (Sinha et al., 2002). The young are more willing to experiment with different brands and children are becoming key decision-makers in household purchases (Kaur and Singh, 2007). Since around 54\% of Indians are below the age of 25 years (India Brand Equity Foundation Report, 2017), there is tremendous scope for brand penetration in India.

\section{Factors influencing consumer behaviour for purchase of luxury brands}

In the earlier days the term luxury was applied to products that were rare and scarce and available to a small segment of the people (Sriviroj, 2007). Today the luxury product market has increased manifold. The Millennials and Generation $Z$ are spontaneously aware of the luxury brands which reflect their desires and fantasies and luxury brands provide them with social status, comfort, good quality and self- esteem. El Adly \& Ismail (2007), identifies 'luxury' as a factor attracting shoppers to shop for a particular product or brand. From an Indian perspective, consumers want value for money and they purchase luxury goods for self - identity and well-being.
Purchasing certain branded luxury goods help them to display their own tastes and values. For some it serves to fulfil the emotional needs where they see luxury as an indulgence of their senses.

\section{E. Luxury brand management by retailers}

Jean - Noel Kapferer and Vincent Bastien (2009) highlight that luxury is in fashion. The luxury strategy unveils how in any market, including $\mathrm{B}$ to $\mathrm{B}$, a company can learn from luxury strategies to differentiate itself profitably. Jonas Hoffmann and Ivan Coste - Maniere (2011) give an insight into luxury management through a strategic approach in their research piece, analyzing the impact of online social networks and the role of emerging markets. The author takes an experiential approach and defines luxury as items which provide extra pleasure by flattering all sense at ones. Michel Chevalier and Michel Gutsatz (2012) describes that luxury retail management is a gold-plated ticket to the glamorous world of luxury retail. The current generation is mostly influenced by posts on social media and other online media. So, the marketing campaigns to attract them should be people-centered rather than a product-centered approach. This will help the luxury market to keep growing with increasing buying power.

\section{RESEARCH GAP}

All the previous studies reviewed were related to various theories and concepts of luxury brands, issues on luxury brands entering the Indian market, challenges faced by the marketers, etc. There is not much literature evidence pertaining to the development of a marketing plan which that will anchor and position luxury brands in the Chennai market. With every consumer having an individual decision making style and preference during shopping, it becomes vital for retailers and luxury marketers to understand the dynamics of a consumer's decision making style. This wide research gap induced the researcher to analyse the major factors influencing consumers to purchase luxury brands. The following research gaps are identified after exploring the previous research works:

- The emergence of luxury brand culture in Chennai.

- Shopping styles exhibited by consumers during shopping trips.

- Major factors influencing consumers to purchase luxury brands.

- Developing a marketing plan to anchor luxury brands in Chennai.

\section{RESEARCH METHODOLOGY}

\section{A. Research objectives}

- To explore the growth of luxury brands in the city of Chennai.

- To explore the luxury brand preferences and consumption patterns of Chennai consumers in the luxury market segment. 
- To investigate the relationship between consumer demographic variables and luxury brand preferences.

- To propose implications for retailers to build marketing strategies that will motivate consumers to consume luxury products.

- To formulate a model for the successful luxury brand anchoring in the Chennai retail market.

\section{B. Research design}

The present study is based on an innovative and analytical research design. This research has adopted quantitative research.

\section{Scope, Sample and Time frame}

- The questionnaires were distributed to consumers in three shopping malls in Chennai - Express Avenue, Pheonix Market City and Bergamo Mall.

- These three malls were selected by the researcher as most of the luxury brands that entered the Chennai retail space have anchor stores in these malls.

- The total number of respondents are distributed as follows:

Table -I: Sample distribution

\begin{tabular}{|c|c|}
\hline Shopping malls in Chennai & Number of respondents \\
\hline Express Avenue & 45 \\
\hline Phoenix Market City & 45 \\
\hline Bergamo mall & 60 \\
\hline Total & 150 \\
\hline
\end{tabular}

- The research was carried out between November 2018 and April 2019.

\section{Sampling technique}

In this study convenience sampling technique has been employed to select the sample.

\section{E. Reliability and Validity of the research instrument}

The Cronbach's Alpha values for the pilot study of 30 samples was 0.855 , which possessed the variance at $85.5 \%$ level. Hence it was found to be suitable to carry out the study.

\section{F. Tools of analysis}

- SPSS 20 was used for analysing the data.

- Percentage Analysis has been applied to describe the demographic profile of consumers.

- Exploratory Factor Analysis (EFA) has been used to identify the factors responsible for the purchase behaviour of consumers while purchasing luxury products and brands.

- Cluster Analysis has been applied to know the natural grouping of the respondents based on their perceptional differences regarding the purchase of luxury products and brands.

- One Way Analysis of Variance (ANOVA) has been used to study the influence of the demographic profile of respondents on various factors influencing the purchase behaviour of consumers while purchasing luxury products and brands.

- Structural Equation Model (SEM) has been employed to develop a model for successful luxury brand anchoring in the Chennai retail market

\section{RESULT AND DISCUSSION}

\section{A. Demographic profile of respondents}

- A majority of $53 \%$ of respondents were in the age group of $18-25$ years. This age group is the most frequent buyer of luxury products and brands. And only $2 \%$ of the respondents were above the age of 56 years.

- A high margin of $61 \%$ of respondents were female consumers.

- A majority of $56 \%$ of respondents had a bachelor's degree and $35 \%$ of respondents had a master's degree. None of the respondents had a professional degree or had an educational qualification lower than high school.

- $48 \%$ of respondents are students, either studying in school or in college. The number of students purchasing luxury products and brands is higher when compared to the other groups of consumers. None of the respondents belonged to the retired category or unemployed category.

- In the monthly income category, $27 \%$ of the respondents had a monthly income of ₹ 90,000 to ₹1,10,000 and only $7 \%$ of respondents had a monthly income of less than ₹30,000.

- $49 \%$ of the respondents did not have dependents and only $4 \%$ of the respondents had more than 3 dependents.

\section{B. Respondents preferences regarding luxury brands and products}

- The study revealed that $71 \%$ of the respondents preferred to purchase luxury products and brands over other goods.

- $55 \%$ of respondents prefer to shop at shopping malls for luxury products as they feel that malls have lots of variety under one roof. Respondents don't prefer to shop much in online portals for luxury products as only $21 \%$ of them prefer to do so.

- Luxury watches were the most sought after luxury purchases by respondents as $28 \%$ of them had purchased a luxury watch. $25 \%$ of consumers purchased luxury brands under the category of clothes and apparels. $24 \%$ of respondents have purchased luxury fashion accessories and cosmetics. $18 \%$ of respondents purchased luxury handbags and $5 \%$ of respondents had purchased luxury high end electronics and gadgets.

-74\% of respondents purchased luxury products every 6 months and only $3 \%$ each of the respondents purchase luxury products on a monthly and a very rare basis.

- $26 \%$ of the respondents get information about luxury brands and products from social media handles. $23 \%$ and $22 \%$ of the respondents gather information about luxury brands from newspaper / magazines and television respectively. 


\section{An empirical exploration of consumer buying behaviour in the age of luxury branding - With special reference to the Chennai retail market}

- A majority of $91 \%$ of respondents feel that possession and the usage of luxury brands have an impact on the consumer's personality.

\section{Impact of price on luxury products purchase}

$.79 \%$ of consumers are willing to purchase luxury products even when there is an increase in the prices of the products.

- $32 \%$ prefer to purchase luxury goods due to quality, $27 \%$ for social status and $18 \%$ because they can afford to it.

- 70\% of the respondents feel that offers and discounts have an effect on the purchase of luxury products as a pricing discount or a seasonal offer might attract new customers to a brand.

- 79\% feel that a high pricing strategy does not have an impact on the purchase of luxury products because loyal consumers will always want to purchase their favourite brand whatever be the price.

$-24 \%$ have an opinion that luxury brands are being bought at a less frequency due to the availability of duplicate brands in the market.

- $15 \%$ of respondents value premium pricing and the number of years of experience in the industry as the criteria when purchasing a luxury brand.

\section{Chennai - A luxury market destination}

- $35 \%$ have an opinion that Chennai is a destination for luxury brands. On the other hand a majority of $65 \%$ of respondents feel that Chennai has not yet established itself as a luxury destination. This calls for a lot of brand building strategies to be undertaken by luxury brand retailers.

- $63 \%$ feel that luxury brands should be anchored in shopping malls as they will have more space and options and 30\% want luxury brands to be anchored at standalone stores.

- $48 \%$ feel that luxury brands are purchased less due to the availability of competing brands at a lesser price in the market.

- The most preferred luxury brands in Chennai market are Gucci, Calvin Klain, Tommy Hilfiger, Louis Philippe, Zara, Mark \& Spencers, Woodland, Adidas, Nike, Rolex, Tissot, Forever and Apple.

\section{E. Identification of factors influencing the purchase of luxury brand / products and grouping of consumers based on the influencing factors}

In order to enumerate the various factors influencing the purchase of luxury products, Exploratory Factor Analysis (EFA) has been used. In this study a set of 22 statements pertaining to the respondents preference to purchase luxury products and brands have been framed. The consumers were asked to rate the statements on Likert's 5 - point scale. The responses were then subject to factor analysis through Principal Component Method to identify the predominant factors.

The 6 factors which are extracted from the 22 variables pertaining to the factors influencing consumers to purchase luxury brands/products are appropriately named and explained below with the factor loadings:

Factor 1 - The Chennai retail market has opened to modernization and international best practices, which has led to newer national and international luxury players entering the market and occupying more retail spaces (Venkatesan, N., \& Mahalakshmi, V., 2009). Consumers are also more than happy to use a variety of luxury goods and products that are high in quality and superiority. This factor encompasses the following variables:

- Luxury products have the best quality (0.882)

- Luxury products are superior (0.856)

- Luxury products are sophisticated (0.798)

Hence this factor is named as "functional value".

Factor 2 - Consumers tend to purchase luxury products and brands for their status symbol. Usage of luxury products and brands among celebrities and famous personalities is a very important factor that influences the common man to purchase luxury goods. Consumers feel that purchasing and owning a luxury brand will give them an edge over their peers and evoke positivity in their behaviour. This factor encompasses the following variables:

- Buying luxury products is to show my status (0.713)

- Luxury products are popular among celebrities (0.601)

- Luxury products evokes positive feelings in me (0.502)

- Luxury products brings pleasure to me (0.403)

- Luxury products communicate who I am to others (0.3) Hence this factor is named as "symbolic value".

Factor 3 - Customer experience is an emotional and subjective experience that consumers inherit during shopping. During a purchase decision, consumers look for experience. Consumers feel that luxury products and brands are very attractive and stunning when compared to other non-luxury categories. The unique features and style quotient of luxury brands influence consumers to prefer them over other brands. A successful retailer is the one who understands the link between consumer preferences and shopping experience of the consumer (Wilhelm \& Mottner, 2005). This factor encompasses the following variables:

- Luxury products are attractive (0.701)

- Luxury products are unique $(0.643)$

- Luxury products are stunning. (0.525)

- Luxury products provide a sense of experience and adventure to me. (0.434)

Hence this factor is named as "experiential value".

Factor 4 - Society plays a very important role in every consumers purchase decision. Consumers feel that luxury products and brands have a social standing as they give a good impression to the person who possess one. Consumers have a strong feeling that luxury products and brands gives them confidence to face the society. This factor encompasses the following variables:

- Before purchasing luxury brand products, I see what impact it has on others (0.662)

- My friends and I buy the same luxury brands / products (0.587) 
- Before purchasing luxury brand products, I see what kind of people buy the same brand (0.447)

- I focus to make an impression on others through luxury brands (0.41)

Hence this factor is named as "social influence".

Factor 5 - Luxury products and brands have a positive perception among consumers. Consumers feel that luxury brands with a higher price tag provide better quality. Consumers have a strong perceptional value for luxury brands as they feel that luxury products will make their life style better.

This factor encompasses the following variables:

- Luxury brand with a high price means good quality compared to other brands $(0.602)$

- Purchasing luxury brands and products is self-gifting for myself (0.459)

- My life would be better if I owned luxury products $(0.455)$

Hence this factor is named as "brand perception".

Factor 6 - The new age consumer is very 'self-concept' oriented. Self - actualizing and social affiliation personal values like for respect, self - fulfilment and sense - of accomplishment, are positively related to a consumer's favourable attitude toward the purchase of luxury brands and products. This factor encompasses the following variables:

- Luxury brands and products enhance my appearance (0.592)

- Achieving greater success is the most important aspect for me (0.432)

- Luxury products make me noticeable in society (0.321)

Hence this factor is named as "self enhancement".

The statistical results for Factor analysis are provided in Table II.

Table - II: Combined table showing factor loadings of luxury product purchase variables, communalities, Eigen values, percentage of variance and cumulative percentage of variance. (Principal Component Analysis with Rotated Component Matrix)

\begin{tabular}{|c|c|c|c|c|c|c|c|}
\hline 気 & 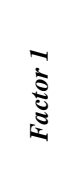 & 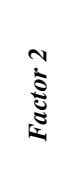 & 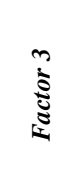 & $\frac{7}{\mathbb{3}}$ & 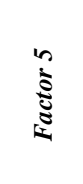 & 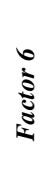 & 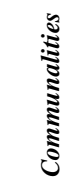 \\
\hline $\mathrm{C} 1$ & 0.882 & & & & & & 0.706 \\
\hline $\mathrm{C} 2$ & 0.856 & & & & & & 0.679 \\
\hline C3 & 0.798 & & & & & & 0.476 \\
\hline C7 & & 0.713 & & & & & 0.479 \\
\hline C8 & & 0.601 & & & & & 0.433 \\
\hline C9 & & 0.502 & & & & & 0.65 \\
\hline $\mathrm{C} 10$ & & 0.403 & & & & & 0.662 \\
\hline $\mathrm{C} 12$ & & 0.3 & & & & & 0.656 \\
\hline $\mathrm{C} 4$ & & & 0.701 & & & & 0.546 \\
\hline C5 & & & 0.643 & & & & 0.548 \\
\hline C6 & & & 0.525 & & & & 0.436 \\
\hline C13 & & & 0.434 & & & & 0.667 \\
\hline C14 & & & & 0.662 & & & 0.602 \\
\hline $\mathrm{C} 15$ & & & & 0.587 & & & 0.442 \\
\hline $\mathrm{C} 16$ & & & & 0.447 & & & 0.485 \\
\hline C17 & & & & 0.41 & & & 0.65 \\
\hline $\mathrm{C} 18$ & & & & & 0.602 & & 0.637 \\
\hline C19 & & & & & 0.459 & & 0.502 \\
\hline
\end{tabular}

Published By:

Blue Eyes Intelligence Engineering \& Sciences Publication

\begin{tabular}{|c|l|l|l|l|l|l|l|}
\hline C20 & & & & & 0.455 & & 0.707 \\
\hline $\mathrm{C} 11$ & & & & & & 0.592 & 0.553 \\
\hline $\mathrm{C} 21$ & & & & & & 0.432 & 0.573 \\
\hline $\mathrm{C} 22$ & & & & & & 0.321 & 0.436 \\
\hline $\begin{array}{c}\text { Eigen } \\
\text { Values }\end{array}$ & 2.536 & 2.519 & 2.303 & 2.106 & 1.516 & 1.345 & 12.325 \\
\hline $\begin{array}{c}\text { \% of } \\
\text { Variance }\end{array}$ & 11.699 & 8.881 & 8.872 & 8.374 & 7.122 & 6.824 & \\
\hline $\begin{array}{c}\text { Cumulat } \\
\text { ive \% } \\
\text { of } \\
\text { variance }\end{array}$ & 11.699 & 20.581 & 29.453 & 37.827 & 44.949 & 51.773 & \\
\hline
\end{tabular}

\section{F. Grouping of respondents based on Cluster Analysis}

Cluster analysis has been used to group Chennai consumers based on the factors that have an impact on their purchase decision of luxury products and brands. This study uses $\mathrm{K}-$ means Cluster analysis (MacQueen, J., 1967) to classify the sample into heterogeneous groups that are homogeneous within themselves. The total average scores of these factors classify the sample unit in the following way:

Table - III: Distribution of the respondents among the three clusters of the factors influencing purchase of luxury products and brands

\begin{tabular}{|c|c|c|}
\hline Clusters & Number of respondents & Percentage (\%) \\
\hline Cluster 1 & 72 & 48 \\
\hline Cluster 2 & 32 & 21 \\
\hline Cluster 3 & 46 & 31 \\
\hline Total & 150 & 100 \\
\hline
\end{tabular}

From table III it is observed that the sample is more or less equally distributed among the three clusters.

Characteristics of the clusters

Table 4 presents the final respondents cluster centres for factors influencing the purchase of luxury brands and products. This reveals the characteristics traits of the respondents with respect to their preference of luxury purchases.

Table - IV: Final respondents cluster centres for factors influencing the purchase of luxury products

\begin{tabular}{|c|c|c|c|}
\hline \multirow{2}{*}{$\begin{array}{c}\text { Factors influencing purchase of luxury } \\
\text { products / brands }\end{array}$} & \multicolumn{3}{|c|}{ Clusters } \\
\cline { 2 - 4 } & $\mathbf{1}$ & $\mathbf{2}$ & $\mathbf{3}$ \\
\hline Functional value & 4.38 & 3.84 & 3.84 \\
\hline Symbolic value & 3.74 & 2.89 & 2.87 \\
\hline Experiential value & 4.25 & 3.68 & 3.76 \\
\hline Social influence & 4.12 & 3.58 & 3.71 \\
\hline Brand perception & 3.15 & 2.96 & 3.89 \\
\hline Self enhancement & 4.21 & 3.63 & 3.66 \\
\hline
\end{tabular}

The respondents were grouped based on their perceptional differences and factors influencing the purchase of luxury products and brands: 


\section{An empirical exploration of consumer buying behaviour in the age of luxury branding - With special reference to the Chennai retail market}

- Cluster 1 - Dynamic Consumers - This cluster consisted of $48 \%$ of the respondents who exhibit high levels of agreeableness to the factors of influencing the purchase of luxury brand sand products. This consumer group seems to be enjoying the splurging up of luxury brands across the Chennai retail market and is ready to try out major national and international brands that are occupying retail spaces in Chennai. For them purchasing a luxury brand adds a lot of social value and status.

- Cluster 2 - Rational consumers - This cluster consisted of $21 \%$ the respondents who have weak qualities of brand perception. This cluster group goes shops for luxury brands and products not for the sole purpose of consumption and the need to purchase it. They are very rational in their buying behaviour.

- Cluster 3 - Intelligent Consumers - This cluster consisted of $31 \%$ of the total respondents, who are highly evaluative of the luxury brands that they purchase and use. This consumer group gives equal importance to quality, functional value, experiential value and brand perception. They prefer to buy luxury brands and products for actual consumption.

\section{G. Influence of consumer's demographic variables on the factors influencing their purchase of luxury products and brands}

experiential value when they purchase luxury products. They do not purchase products and utilities for the household but purchase for self-indulgence.

- Respondents with a Master's degree were highly influenced by the functional value of luxury products. They are constantly browsing across malls and stores before making the actual purchase as they prefer to purchase goods that are best in quality and very sophisticated.

- The working class employed in the private sector felt that symbolic value is very important. For this category of consumers it is very important to show their status to their peers. They feel pleasure and positivity when they purchase a luxury product.

- Public sector employees look for self enhancement when they shop for luxury brands. They feel that luxury brands and products enhance their appearance and makes them noticeable in society.

- Respondents earning more than ₹ 1,30,000 look for self enhancement when they purchase a luxury product. They feel that luxury brands make them feel noticeable in the society.

- Respondents earning ₹ 1,10,000 - ₹ 1,30,000 give importance for brand perception. For this category of consumers purchasing a luxury brand is for the purpose of self - gifting as they feel that their life is better if they owned luxury goods.

${ }^{\mathrm{a} .}$ Source: Computed data

- Respondents earning ₹ 30,000 - ₹ 50,000 felt that

Table - V: Table showing results of One - Way Analysis of Variance (ANOVA)

\begin{tabular}{|c|c|c|c|c|c|c|c|c|c|c|c|c|}
\hline $\begin{array}{c}\text { Demographic } \\
\text { variables }\end{array}$ & \multicolumn{2}{|c|}{ Age } & \multicolumn{2}{|c|}{ Gender } & \multicolumn{2}{c|}{$\begin{array}{c}\text { Marital } \\
\text { status }\end{array}$} & \multicolumn{2}{c|}{ Education } & \multicolumn{2}{c|}{$\begin{array}{c}\text { Profession } \\
\text { Factors }\end{array}$} \\
\hline
\end{tabular}

functional value of a luxury brand is very essential

- Respondents in the age group of 26 - 35 years indulge more in shopping of luxury brands and products. They give a lots of importance for symbolic value and self enhancement. They tend to buy luxury brands and products to boost their self-confidence.

- Female consumers were highly influenced by the "experiential value" as they look for attractiveness and stunning elements when they purchase a luxury brand.

- Male consumers gave importance to the functional value of the product and brand that they purchase. They look for quality and value for money when they purchase a luxury brand. They prefer products that have good durability and functional aesthetics.

- Single / unmarried consumers seek high levels of

They look for quality in the brand that they purchase since they can only spend a moderate amount from their salary.

- Respondents having more than 3 dependents have a large family and need to shop a lot to satisfy the needs and wants of their family members. They are highly influenced by the functional value of luxury products and brands. 
- Respondents with 2 dependents were influenced by society during their purchase of luxury goods. They mostly purchase products that are purchased by their peers and neighbours. They use luxury brands as a means to impress others.

- Respondents having no dependents spent a lot of money on luxury goods as high price is good quality for them.

\section{MODEL DEVELOPMENT FOR SUCCESSFUL LUXURY BRAND ANCHORING IN THE CHENNAI RETAIL MARKET}

In the course of this study data has been collected with respect to the following:

- Demographic profile of the respondents - this includes age, gender, marital status, educational level, profession, monthly family income and the number of dependents of the respondents.

- Shopping preference of the respondents.

- Factors influencing respondent's purchase decision regarding luxury brands and products.

The interrelationship among the variables has been established through the use of several statistical tools. These relationships have been used to construct a model that depicts the interrelationships among the variables. The researcher has developed an model that has revealed the influence of demographic variables on consumer shopping preference and factors influencing them to purchase luxury goods.

\section{PRACTICAL AND MANAGERIAL IMPLICATIONS}

Customer satisfaction has long been recognised as playing an essential role for success and survival in today's competitive environment. The following managerial implications are derived from the study:

- The role of marketing by a firm have been increasing double the fold to attract and retain customers.

- It is incredibly necessary for the executives and brand managers to understand the customers' needs and customize the product offering, as a result of this customers will remain loyal to the organization on a long term basis.

- If product customization is done systematically with managerial insights, then brands can retain their customers and it will be win-win situation for organization and customers as well.

\section{LIMITATIONS OF THE STUDY}

- The study is limited to few luxury malls in the city of Chennai only. The study cannot be generalized to other parts of Tamil Nadu and India.

- Studying consumer behaviour is a very complex process as consumers are influenced by various factors - these factors can differ from one consumer to another consumer and from time to time for the same

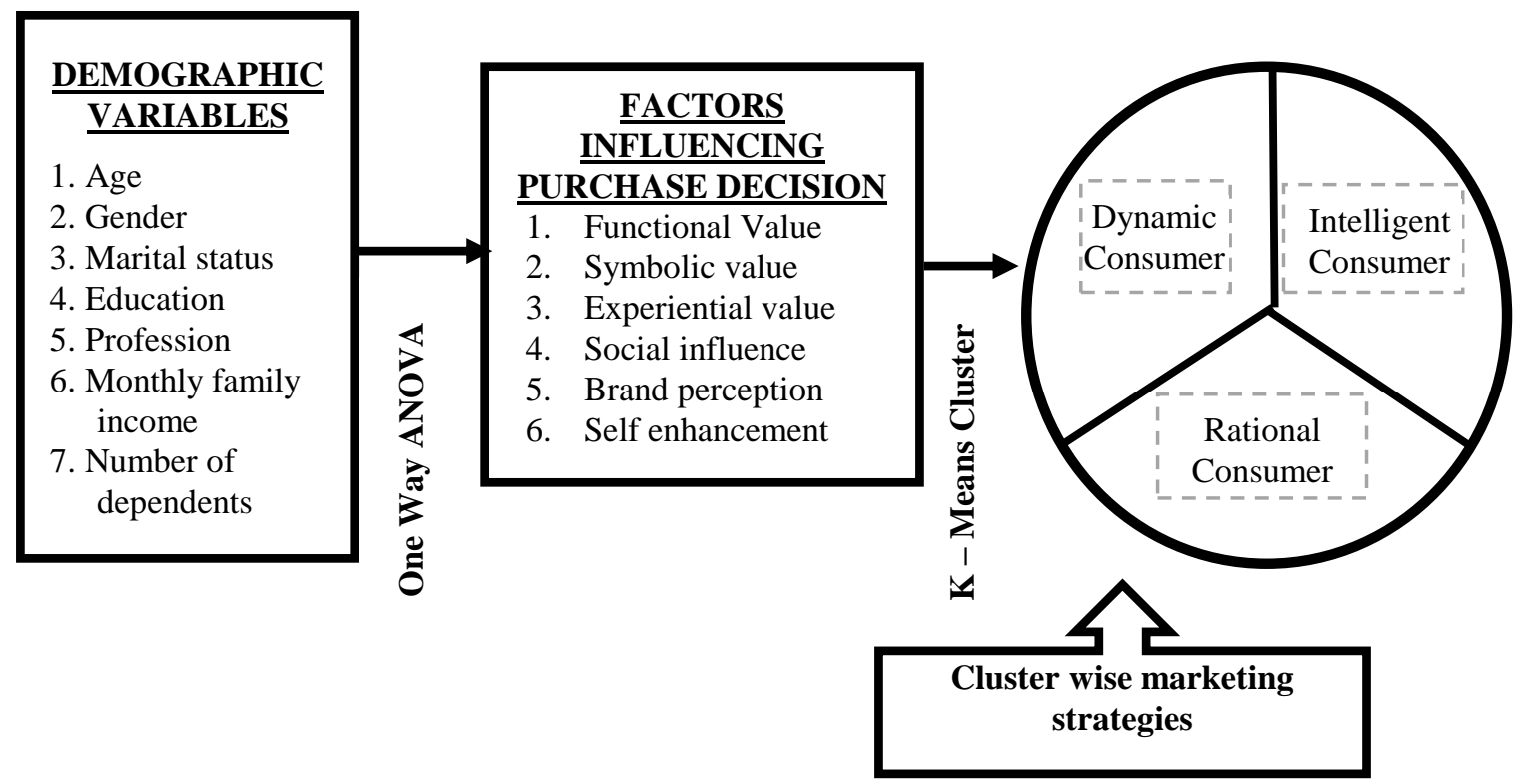

Fig. 1.Structural Equation Model for the successful luxury brand anchoring in the Chennai retail market

The model underlines the fact that retailers and luxury band managers will have to indulge in cluster wise marketing strategies to successfully launch their products and brands. Retailers need to first understand the various factors that influence consumers to purchase a brand / product based on their demographic profile and then develop the marketing strategy. consumer.

- During the course of data collection few respondents were reluctant to divulge information about their shopping habits. 


\section{An empirical exploration of consumer buying behaviour in the age of luxury branding - With special reference to the Chennai retail market}

\section{AGENDA FOR FURTHER RESEARCH}

This study will serve as a threshold for many innovative research ideas and investigations. The agenda for further research is listed as follows:

- This study can be extended to the tier -2 and tier -3 cities of Tamil Nadu as they have a huge potential for modern luxury retailing.

- This study can be extended to the other metros of India and a comparative analysis can be performed.

- An in - depth and comprehensive study of the Indian luxury industry and its impact on the Indian economy and consumerism can be studied.

- Studies can be conducted for materializing effective luxury brand management strategies.

- Global comparisons of consumer purchase patterns can be studied to understand the dynamics of consumer decision making across continents and cultures.

\section{CONCLUSION}

Based on the finding of this research a number of conclusions can be drawn. The research shows that different consumers have different perspective on the basis of luxury brands. It is clearly evident that customers buy luxury brand products on the basis of some secondary objectives like best quality, best design, aesthetics and brand value. Social Media is the top influencer for purchase of luxury brands. Most of the people become aware of the luxury brands through both traditional and modern medium. Thus, the marketers must adopt an effective media channel for the promotion of their brand. As the city of Chennai sees more shopping malls and luxury stand alone stores opening up, it is becoming difficult for retailers to retain customers. Sensing this issue, marketers start relooking into their marketing efforts for gaining customer loyalty. The need for the hour is to attract the customer footfall, convert them into actual buyers and try to retain them in the long run.

\section{REFERENCES}

1. A. Appadurai, "The Social Life of Things. Commodities in cultural perspective". Cambridge University Press, 1986.

2. Glyn Atwal and Soumya Jain, "The Luxury Market in India Maharajas to Masses", Palgrave Macmillan, 2012.

3. W.O. Bearden and M.J. Etzel, "Reference group influence on product and brand purchase decisions", Journal of Consumer Research, vol.9, 1982, pp 183-196.

4. C.J. Berry, "The idea of luxury: A conceptual and historical investigation", Cambridge University Press, 1994.

5. Michael Boroian, and Alix de Poix, "India by Design: The Pursuit of Luxury and Fashion", New Jersey, Wiley Publication, 2009.

6. Neha Bothra, "Luxury Brand and Luxury Market in India: From Class Consumers to Closet Consumers", IOSR Journal of Business and Management, vol.15(1), 2013, pp 18 - 27.

7. Purvita Chatterjee, "Luxury Brands May Not Have It Easy In India". The Hindu, Business Line, 2016.

8. Michel Chevalier and Gerald Mazzalovo, "Luxury brand managementA world of privilege", John Wile, 2012.

9. V. De. Barnier, I. Rodina, \& P. Valette-Florence, "Which luxury perceptions affect most consumer purchase behavior? A cross-cultural exploratory study in France, the United Kingdom and Russia" Proceedings of the International Marketing Conference, 2006.

10. El - Adly, Mohammed Ismail, "Shopping malls attractiveness: A segmentation approach", International Journal of Retail \& Distribution Management, vol. 35(11), 2007, pp. 936 - 950.

11. Jonas Hoffman and Ivan Coste Maniere, "Luxury strategy in action", UK, Palgrave Macmillan, 2011
12. India Brand Equity Foundation Report, 2017. [Online] Available: https://www.ibef.org/

13. Prerna Jain, Indian Consumer Market, 2013. [Online] Available: http://prernajaindotme.wordpress.com

14. Jean-Noel Kapferer and Vincent Bastein, "The Luxury Strategy: Break the rules of Marketing to build Luxury brands", UK, Kogan, 2009.

15. P. Kaur and R. Singh, "Uncovering retail shopping motives of Indian youth, Young Consumers", 2007. [Online] Available: https://www.emeraldinsight.com/2007

16. S. Kemp, "Perceiving luxury and necessity", Journal of Economic Psychology, 1998.

17. Indian Consumer Market - A change from Pyramid to sparkling Diamond, KS Oils Ltd, 2014. [Online] Available: http://www.ksoils.com/white paper.htm

18. J. MacQueen, "Some methods of classification and analysis of Proceedings of the Fifth Berkeley Symposium on Mathematical Statistics multivariate observations". L.M. Le Cam \& J.Neyman (Eds.), and Probability, Berkeley, CA: University of California, 1967, pp. 281 $-207$.

19. A. Nia and J.L. Zaikowsky, "Do counterfeits devalue the ownership of luxury brands", Journal of Products and Brand Management, vol. 9(7), 2000 , pp. $485-497$.

20. Piyush Kumar Sinha, Arindam Banerjee and Dwarika Prasad Uniyal, "Deciding Where to Buy: Store Choice Behaviour of Indian Shoppers", Vikalpa: The Journal for Decision Makers, Sage publication, 2002.

21. Retailers Association of India (RAI), 2019. [Online] Available: https://rai.net.in/

22. Werner Sombart, "Luxury and capitalism", University of Michigan Press, 1967.

23. K. Sreedevi, "Chennai malls all set for explosive growth", Deccan Chronicle, (2013, 8th February), p. 2A.

24. S. Sriviroj, "Purchasing luxury goods: Consumer behaviour of international students in the UK", Unpublished doctoral dissertation, University of Nottingham, United Kingdom. 2007

25. N. Venkatesan and V. Mahalakshmi, "Role of retailing and growth of hypermarkets in India", Indian Journal of Marketing, 2009, pp 3-11.

26. Wendy Bryce Wilhelm and Sandra Mottner, "Teens and Shopping Mall Preferences: A conjoint analysis approach to understanding the generational shift toward an experience economy", Journal of Shopping Center Research, vol. 12(1), 2005, pp 23 - 52.

27. [Online] Available: https://www.ibef.org/industry/indian-consumer-market.aspx

\section{AUTHORS PROFILE}

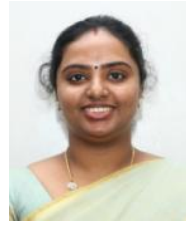

Dr. Nisha $U$ is currently serving as the Head of the Department of Commerce (Marketing Management) at M.O.P.Vaishnav College for Women. She acquired her Ph.D from the University of Madras in Retail Marketing and Consumer Behaviour. She has served as resource person and an invited speaker at The Southern India Regional Council - Institute Of Cost And Works Accountants Of India and at Stella Maris College. Dr. Nisha has several international and national publications to her credit in the field of Advertising, Retail Marketing, Consumer behaviour and Services Marketing. 